\title{
Attending Euripides: Philo of Alexandria's Dramatic Appropriations
}

\begin{abstract}
Philo of Alexandria speaks with fondness of his experience in the audience at a performance of Euripides, and throughout his corpus he quotes from this playwright on 21 occasions and from 10 different plays. As a writer whose driving interest was the exposition of Jewish scriptures in conjunction with Hellenistic philosophy, Philo's repeated recourse to tragedy is noteworthy and illustrative of his intellectual milieu. This study will consider why and how Philo deploys Euripides. Most often, his quotations are gnomic sayings and philosophical proof texts which were common currency among contemporary writers. With respect to at least one drama, however, the satyr-play Syleus, Philo engages in a more extensive discussion of its context, producing a string of five fragments, four of which are unattested elsewhere. By surveying his use of Euripides, I aim to make evident the extent to which Philo was dependent upon received philosophical and literary sources, along with moments of his own innovation as he reads Attic drama in connection with his distinctive Jewish religious commitments.
\end{abstract}

At first glance, Philo of Alexandria and Euripides appear to have little in common. They were divided by four centuries, inhabited separate continents, and identified with different religious traditions. Euripides' works were performed at Dionysiac festivals; his plays both celebrate and interrogate the ideals of Greek religion and society; by contrast, Philo's prose treatises are steeped in Jewish thought and frequently engage in the exposition of authoritative scriptural texts. In some other respects, however, the intellectual projects of Philo and Euripides converge. Both inherited established generic and literary models - dramatic conventions for Euripides, and accepted modes of biblical exegesis for Philo. Each adopted these, respectively, while at the same time transforming them in numerous and, at times, unexpected directions. And while their remarkable literary outputs had profound influences, the trajectory of their innovations were not directly realized: Euripides is the last of the celebrated Attic playwrights, and Philo's distinctive approach to the Bible would largely not be taken up by his fellow Jews, though many early Christians would appropriate it.

Additional similarities are evident. Euripides and Philo inherited corpora of literature consisting of heroic legends, whose meanings they probed and tested; for both, cultural or mythological heroes become, on occasion, vehicles for expressing contemporary philosophical problems. For instance, in a fragment of Euripides' Chrysippus (fr. 839 Kannicht), the chorus relate the cosmological views of the philos- 
opher Anaxagoras. ${ }^{1}$ Analogously, Philo depicts the divine calling of Abraham from the land of the Chaldeans as an experience akin to Plato's allegory of the cave, as the biblical patriarch awakens to the tenets of Middle-Platonism (Abr. 68-84). Elsewhere, both writers deploy mythology to illustrate their moral ideals, for example, that freedom with death is preferable to life as a slave. ${ }^{2}$ In short, Euripides and Philo were critics of their respective cultures who appropriated traditional religious and mythological materials while at times filling them with radically new meanings.

These cursory observations foreground potential points of salience for thinking about Philo's reception of Euripides. That Philo, a Jewish philosophical interpreter of scripture, should have paid close attention to Euripides is, to my mind, inherently interesting. Indeed, Philo quotes from Euripides as many as 21 times, plus eight possible allusions, from 10 plays distributed across 14 of his treatises. ${ }^{3}$ By comparison, he quotes Aeschylus 6 times and Sophocles once, and Homer is quoted 25 times; these distributions reflect broader literary preferences of this time period. ${ }^{4}$ In this essay, my aim will not be an exhaustive treatment of these; rather, by analyzing a few representative examples, I hope to address larger questions of how and why Philo appropriates Euripides. That is, first by what means did he encounter the playwright, and what sources did he use? Here, a range of possibilities are considered, including attending public performances, reading directly from individual plays, and second-hand quotations from florilegia or other prose authors. ${ }^{5}$ Second, for what purpose did Philo deploy Euripidean poetry? Here likewise there is a variety of potential reasons: as moral exempla, as proof texts for philosophical doctrine, as sources of gnomic wisdom, or as advertisements of his level of education. These issues are largely interconnected and will resurface throughout the following analysis, which is organized primarily around two philosophical treatises. In the first section, I consider De aeternitate mundi in which Philo employs an oft-quoted fragment from the Chrysippus. Second, I turn to the Quod omnis probus liber sit, which involves the highest volume of Euripidean material. Here, I survey several relevant passages, culminating in Philo's most expansive use of a Euripidean drama, the Syleus. Finally, in the third section I take up Philo's claim in the same treatise to have

1 See below pp. 261-263.

2 See below on Polyxena and Heracles, pp. 264-268.

3 These are tabulated from Lincicum 2013b. Euripides is mentioned by name three times in the corpus, all in the Quod omnis probus liber sit $(99 ; 116 ; 141)$.

4 These relative frequencies can be compared with surviving papyri. Garland 2004, 53 enumerates 176 for Euripides, 38 for Sophocles, and 35 for Aeschylus. See also Cribiore 2001, 198-99; Morgan 2003.

5 Poetic anthologies, or florilegia, were commonly collected and re-used widely in antiquity. For discussion, see Chadwick 1969; Konstan 2010. Aristobulus, for example, a second-century BC Jewish author, compiled "pagan” verses (esp. from Homer, Hesiod, and Linus) in support of Jewish beliefs and practices, such as the Sabbath (e.g., in Eus. Praep. ev. 13,12,9-16); similarly Ps.-Justin, De monarchia 2-5 contains excerpts especially from dramatic passages (including some forgeries) with similar objectives; see Gruen 2001, 72-74; Doering 2005, 4-15. 
attended a performance of Euripides, exploring the significance of Philo placing himself in the audience.

There are numerous reasons why scholars of Euripidean drama and its reception might turn to Philo as a resource. Most immediately, he preserves several otherwiselost fragments from the satyr-play Syleus, and given the poor preservation of this genre, this is most useful. In most cases, however, Philo's Euripidean material is attested elsewhere. Consequently, his distinctive contribution is that he offers a perspective on Euripides from the vantage point of educated Jewish culture. That is, Philo's use of Euripides reveals the breadth of the playwright's popularity and influence across antiquity, which were not limited to "pagans.” Moreover, given Philo's own subsequent reception, his appropriation of Euripides may also have influenced early Christian intellectuals after him. ${ }^{6}$

\section{Euripides' Chrysippus in De aeternitate mundi}

In De aeternitate mundi one popular fragment of Euripides' Chrysippus (fr. 839 Kannicht) is repeated on three occasions in connection with the nature of the cosmos (Aet. 5, 30, 144; and also Leg. 1,7), making it (along with the Syleus) the most quoted Euripidean play in the Philonic corpus. ${ }^{7}$ Construal of how and why Philo deploys this excerpt is distinctly challenging, however, because the treatise is a doxography and reports numerous ideas and arguments that are not Philo's own. ${ }^{8}$ De aeternitate

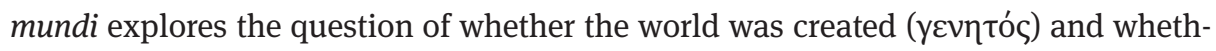
er it is destructible ( $\alpha \varphi \theta \alpha \rho \tau o \varsigma)$. Three options are possible, each of which corresponds to particular philosophical schools. First, that the world is created and destructible (Stoics, Democritus, and Epicurus); second, that it is uncreated and indestructible (Aristotle); and, third, that it is created and indestructible (Plato). Philo's position agrees with the third, which he argues was also held by Hesiod and taught by Moses before him (Aet.17-19). In the remainder of the treatise (20149), he outlines the arguments for the Aristotelian view, and closes by anticipating

\footnotetext{
6 Several studies of Philo and Greek drama have appeared in recent years: see Koskenniemi 2006; Bloch 2009, 66-67, 70 -72; Jay 2013, 221-232; Lincicum 2013a; Jay 2017; Friesen 2017. On Philo and classical poetry more broadly, see also Koskenniemi 2010; Berthelot 2011; Niehoff 2012; Nieto Hernández 2014; Friesen 2015a. Also especially relevant for Philo's intellectual and literary milieu and his educational background: Alexandre 1967, 105-129; Mendelson 1982, 25-46; Collins 1997, 148 153; Alexandre 2009; Niehoff 2011, 133-185; Koskenniemi 2014.

7 On this treatise, see Arnaldez and Pouilloux 1969; Runia 1981; Niehoff 2006; Fuglseth 2006; Runia 2008, 34-39.

8 Some Philo scholars have questioned its authenticity precisely because the majority of the treatise advocates a position clearly at odds with that of Philo. Now, however, many are inclined to accept it: see esp. Arnaldez and Pouilloux 1969, 12-37; Runia 1981; Niehoff 2006; Runia 2008, 34. Against authenticity, see Fuglseth 2006.
} 
his exposition of counter-arguments (150); but this was either not completed or has not survived.

It is within the context of Philo's exposition of the Aristotelean position that he provides the longest fragment of the Chrysippus:

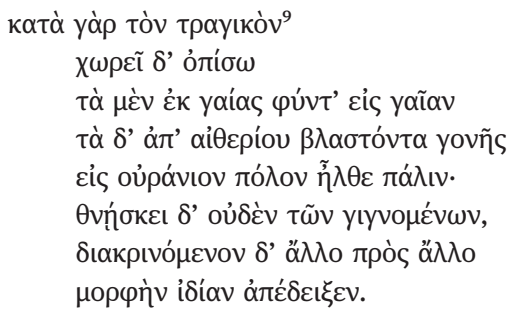

For according to the tragedian,

The things which by nature come from earth return back into the earth, and the things which are born from ethereal stock go back into the heavenly sphere. None of the things coming to be dies, but as one thing dissolves into another, it displays its own form. (Aet. 30; fr. 839,8-14 Kannicht $)^{10}$

It is easy enough to see that this fragment fits well within the context, as it expresses succinctly the eternal nature of matter. ${ }^{11}$ Because these lines are cited as support for the Aristotelean position he is reporting, it is highly probably that Philo derived them from one of his philosophical sources. Indeed, the larger section in which this Euripidean excerpt occurs has been identified as a fragment of Aristotle (Aet. 28-34= Arist. fr. 20 Rose). Likewise, later in the treatise when Philo quotes 3 lines of the same fragment (Aet. 144), it falls within a passage that Philo himself attributes to Theophrastus (Aet. 117-149 = Theophr. fr. 184 Sharples). Of course, it is impossible to be certain to what extent Philo maintains or alters the language of his doxographical materials, and some have argued that the style is decidedly Philo's own. ${ }^{12}$ As

9 Briefer quotations of the same fragment (839.12-14) occur at Aet. 5, 144; and Leg. 1,7. Cf. the intro-

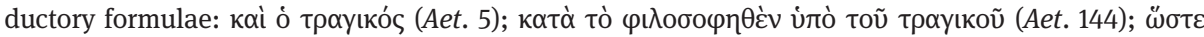

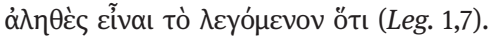

10 All translations are my own throughout.

11 On the relationship between Euripides and contemporary metaphysics and theories of cosmic origins, see Dillon 2004, 49-61.

12 This is argued by Wiersma 1940 on the basis of vocabulary and prose-style; see also Kidd 1996, 137; Sedley 1998, 333. In fact, Sedley takes the quotation of fr. 839 Kannicht in Aet. 144 as evidence for Philonic intervention because the same fragment had already been quoted at 5 and 30; however, it seems just as likely that Philo found this in his Aristotlean sources, that of Theophrastus or otherwise. Runia 2008 has clearly demonstrated the challenges of precisely delineating Philo's sources in this treatise, and his conclusions caution against certainty: "There is no way of determining whether Philo used this or any other source directly. The various arguments in De aeternitate most likely have a disparate origin. Philo's doxography makes use of existing source material, but its innovative structure is his own contribution" (at 39). On Philo and philosophical doxography, see also Lévy 2005. 
such, the possibility that Philo himself inserted the poetic fragment within his philosophical sources cannot be excluded, though it seems more likely, to me at least, that he encountered it already imbedded within them.

It is also noteworthy that by the time of Philo this Euripidean fragment had developed a life of its own within philosophical discourse quite removed from any dramatic context. Lines 1-7 are quoted by Sextus Empiricus (Math. 6,17), and Lucretius adapts the entire 14 lines to Latin (2,991-1006). Vitruvius deploys the same lines and takes them as evidence that Euripides was a student of Anaxagoras, and thus a "philosopher of the stage" (philosophus scaenicus, 8 praef. 1); in the context of Vitruvius' argument they support his own claims regarding the necessity of the four elements air, fire, water, and earth - for all life. Numerous others quote the fragment, including Heraclitus (All. 22,11), Marcus Aurelius (7,50), and Clement (Strom. 6,2,23). ${ }^{13}$ As with these other authors, Philo shows little interest in or knowledge of the play itself. While he is aware that it comes from a tragedy, he offers no further details regarding its playwright, speaker, or plot. Indeed, ancient writers who comment on the dramatic content of the Chrysippus do so with a view to one issue, namely, the practice of pederasty (Chrysippus was raped by Laius and in some sources killed himself). ${ }^{14}$ If Philo was aware of this feature of the tragedy, he gives no indication. Indeed, it is unclear how the metaphysical speculation in the fragment quoted by Philo relates to the wider context of the play. ${ }^{15}$

In short: although several questions remain open, Philo's use of the Chrysippus fragment provides a valuable starting point for his engagement with Euripides. In this case, he is concerned with the philosophical aspects emerging from the tragedy quite detached from its dramatic context, which is, of course, perfectly consistent with the playwright's reputation as "the philosopher of the stage." It is most likely that Philo has taken his quote from its place within a pre-existing philosophical tradition, in which this poetic passage had an established function as a proof text. ${ }^{16}$

13 Cf. Pacuvius, Chrysae fr. 6 Ribbeck.

14 See Ael. NA 6,15; VH 2,21; Cic. Tusc. 4,71

15 One might speculate that in fr. 839,1-7 Kannicht, where the chorus celebrates the reproductive fertility of the earth mother (Gaia) and sky god (Zeus), they are advocating for heterosexual relationships in opposition to Laius' violent desire for Chrysippus.

16 Elsewhere I have argued for a similar phenomenon in Philo's use of Hesiod; Friesen 2015a. In Ebr. 150, he quotes Works and Days 287, 289-292 in support of his contention that the road to virtue is more difficult. The same Hesiodic lines were also deployed with similar moral applications by Plato (Rep. 2, 364d; Lg. 4, 718e), Xenophon (Mem. 2,1,20), and Plutarch (De aud. poet. 24D-F). 


\section{Quod omnis probus liber sit: Euripides and Moral Exempla}

Similar processes of poetic appropriation are evident in the Quod omnis probus liber sit. Like De aeternitate mundi, this is a philosophical treatise, though, by contrast, it takes up an ethical topic, namely, the stoic paradox that every good person is free even if enslaved. ${ }^{17}$ The treatise is structured around numerous exempla that corroborate its thesis, most of which come from Greek and Roman culture, commonly known from history, literature, and contemporary society. ${ }^{18}$ It is, of course, not unusual that a learned author such as Philo would employ Greek poetry throughout such a work. Of Philo's 21 quotations from Euripides, 10 occur in the Probus; in addition, more explicitly than any of his other treatises, in the Probus Philo offers programmatic statements regarding the value of poetry: he maintains that it is "fitting

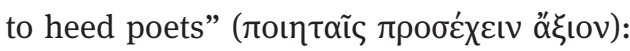

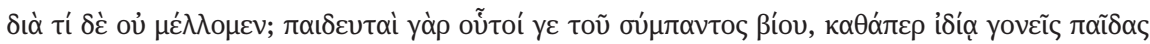

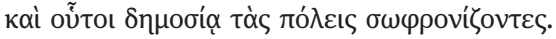

Why shouldn't we? They are educators through our entire life, just as parents train their children in moderation privately, so also they do for their cities publicly. (Prob. 143) ${ }^{19}$

In keeping with this, Philo frequently inserts Euripidean lines as common aphorisms with little or no attention to the source or context. Sometimes these include introductory formulae as in Prob. 22: "The author of the following trimeter is praised by some:

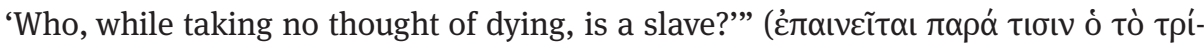

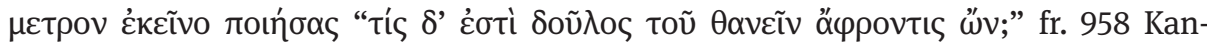
nicht). ${ }^{20}$ But elsewhere there is no formula, as in Prob. 145: "moderate means are suf-

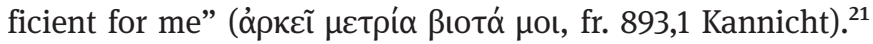

17 On this treatise, see Petit 1974. The same Stoic paradox is discussed in similar ways by Cicero (Paradoxa Stoicorum 5) and Epictetus (Diss. 4,1); for comparison, see Petit 1974, 54-57. Along with clear correlations with Stoicism, Cynic influence on the treatise is also evident. As with Stoicism, Cynicism was concerned with slavery and freedom as moral categories; see Hense 1892; Helm 1906, 141144.

18 Nevertheless the most prominent exemplar for Philo is the Jewish community of the Essenes (Prob. 75-91); cf. his idealization of the Therapeutae in De vita contemplativa. For an outline of the treatise and list of exempla, see Petit 1974, 29-34.

19 Compare the comment of Dio Chrysostom in his Alexandrian Oration that this city lacked dramatic poets, such as those who flourished in Athens where they had the freedom "to reproach not only in-

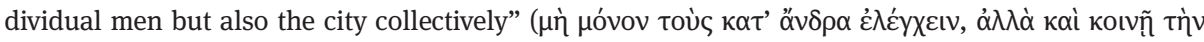

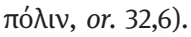

20 The same verse is quoted elsewhere: Plut. De aud. poet. 34B; Cons. ad Apoll. 106D; Cic. Att. 9,2a,2; Clem. Al. Strom. 4,7,49,4.

21 Four lines of this fragment are quoted by Athenaeus $(4,158 \mathrm{e})$. 
On other occasions, however, Philo expresses interest in the context of the drama. For instance, he identifies Polyxena as the speaker of the following lines:

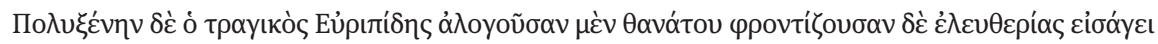
$\delta$ '’ $\tilde{\omega} v$ $\varphi \eta \sigma \mathrm{v}$.

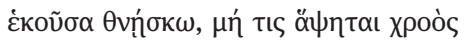

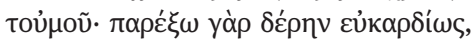

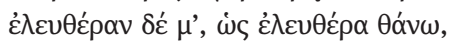

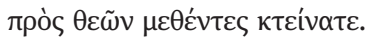

Euripides the tragedian presents Polyxena as paying no heed to death but pondering freedom through what she says:

I die willingly, lest someone touch my body; for I shall offer my neck gladly, but, by the gods, allow me to be free when you kill me, so that I might die free. (Prob. 116, quoting Hec. 548-551)

Here, Philo's citation of Euripides provides him with a moral exemplum illustrating his central thesis regarding the freedom of the virtuous person. Citing additional examples of women and children he deploys an a fortiori argument:

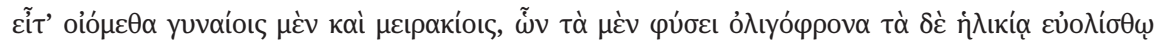

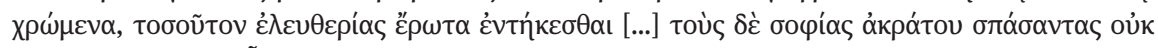

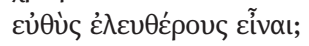

Can we suppose that such a love of freedom be absorbed in women and boys, the former possessing little understanding by nature, the latter an unstable age, but that those who draw in unmixed wisdom not be free immediately? (Prob. 117) ${ }^{22}$

This gendered application of Polyxena is consistent with Philo's ideology elsewhere, as he often portrays moral and spiritual advancement as a progression from feminine to masculine (e.g., Opif. 165; Leg. 2,38-39; Spec. 1,200-201; Post. 177; Ebr. 33, 55, $59-60) .{ }^{23}$ At the same time, as with the Chrysippus discussed above, excerpts from and references to the Hecuba are frequent in antiquity. ${ }^{24}$ Indeed, Polyxena's noble death was a common exemplum and, occasionally, as in Philo, applied with an emphasis on gender. For instance, in a statement attributed to Demosthenes immediately prior to his suicide to circumvent enslavement by Antipater, the orator quotes $\mathrm{He}$ cuba 568-569 and comments, "even a girl did these things; but will Demosthenes

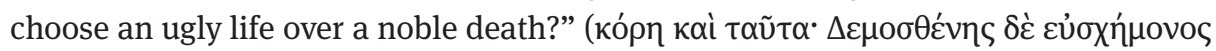

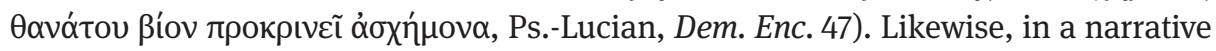
closely dependent on Euripides, Ovid foregrounds Polyxena's gender, portraying her

22 Along with Polyxena, Philo notes a Laconian child who took his own life to avoid becoming a slave (Prob. 114); and certain Dardanian women who, when captured, threw their children into the river to prevent their enslavement (115).

23 See Mattila 1996; Friesen 2015b, 198-206.

24 On reception of the Hecuba generally, see Heath 1987; on Philo in particular, Friesen 2016, 630 639. 
as "a brave and miserable girl, and more than a female" (fortis et infelix et plus quam femina virgo, Met. 13,451). ${ }^{25}$ Given the frequency with which the Hecuba was cited with similar moral applications, there is a strong possibility that Philo encountered these lines already excerpted for use in ethical instruction.

In contrast to these examples, Philo's use of the Syleus in Prob. 99-104 stands out in several regards. ${ }^{26}$ This is by far his most sustained and extensive deployment of a play by Euripides (or any other poet) consisting of 5 fragments (frr. 687-691 Kannicht) totaling 17 lines, and after the first, fourth, and fifth fragments Philo offers plot summary and analysis. Nevertheless, the opening fragment is in some regards characteristic of his use of Euripides elsewhere, as has already been noted above.

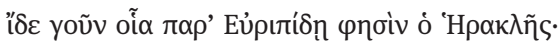

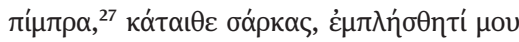

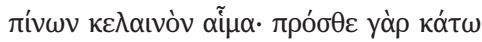

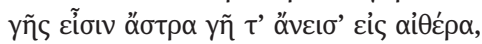

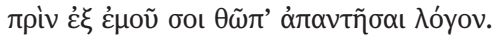

See, then, what kinds of things Heracles says in Euripides:

Ignite and burn up my flesh, be filled with drinking my dark blood; for the stars will come down to earth, and the earth ascend to the sky before a flattering word from me meets you. (Prob. 99; fr. 687 Kannicht)

Like Polyxena, Heracles' willing acceptance of death establishes the nature of true freedom. As Philo notes, to speak a word of flattery is "most befitting a slave" ( $\delta \mathrm{ou}$ -

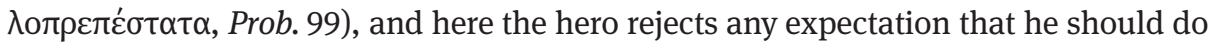
so - he would prefer to die. ${ }^{28}$ Moreover, as with the Hecuba, these lines appear to have had a popular and independent function: the fragment is also attested in Artemidorus (4,59), Eusebius (Praep. ev. 6,6,2), and Michael Psellus (Poemata 21,275276). Philo himself was fond of these lines and quotes them on multiple occasions (Leg. 3,202; Ios. 78; Prob. 25) as he did with the Chrysippus; in each other instance, however, he makes no mention of the identity of the speaker or of the dramatic context. ${ }^{29}$ In short, Philo's quotation of fr. 687 Kannicht has the hallmarks of a popular

25 Additional citations of the Hecuba that focus on Polyxena's heroic courage in death include Plin. Ep. 4,11,9; Hermog. Inv. 4,12; Clem. Al. Strom. 2,23,144,2; see also Sen. Tro. 1118-1164; Lucian, Nigr. 11,8; Pisc. 31,16.

26 For discussion and reconstruction of the Syleus, see Galinsky 1972, 83-84; Sutton 1980, 66-67; Pechstein 1998, 243-283. On Philo's application of this play in Prob. 99-104, see Koskenniemi 2006, 139-141.

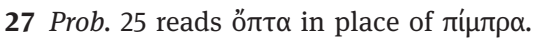

28 On flattery, see also Epict. Diss. 4,1,55.

29 In Prob. 25, this fragment is introduced as a generic response of a free person to the abuses of enslavement: "acting with youthful vigor, he proclaims in response, "roast and burn up my flesh"” (

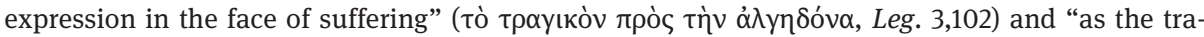


excerpt which, as in other instances, Philo could have accessed second hand via a florilegium or excerpted within a philosophical treatise. ${ }^{30}$

By contrast to Philo's first fragment from the Syleus, his supplementary addition of further quotations and extended exposition of the play differ substantially from his treatment of other Euripidean plays. First, importantly, the remaining four fragments (fr. 688-691 Kannicht) are completely unattested elsewhere. To these, Philo adds relevant details from the plot. Hermes brings the disguised Heracles to the slave market in order to sell him to Syleus as a ruse to destroy the cruel tyrant. Although Heracles endeavors to disguise himself, his heroic character shows through. To illustrate, Philo quotes Hermes' comments:

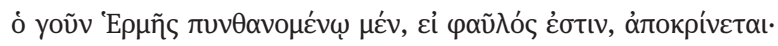

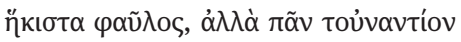

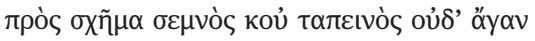

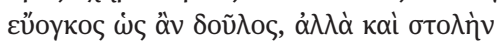

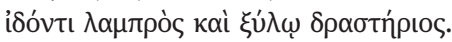

Hermes answers the one inquiring whether [Heracles] is base:

Is he most base? Rather, quite the opposite, he is honorable and not humble in form, nor overly bulky as a slave would be, but to an observer he is sharply dressed and effective with a club. (Prob. 101; fr. 688 Kannicht)

Because of this, a speaker (either Hermes or Syleus) expresses some doubt as to his capability of assuming the role of a slave:

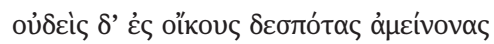

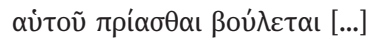

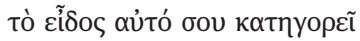

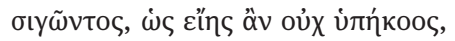

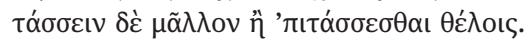

No one wishes to purchase masters for his house that are stronger than himself [...] Though you are silent, your form itself indicates that you would not be obedient, but that you would rather give orders than take them. (Prob. 101; fr. 689-690 Kannicht) ${ }^{31}$

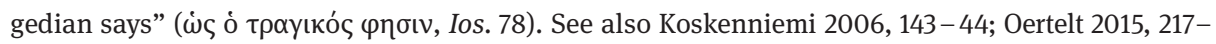
218.

30 The possibility that this fragment existed as an independent excerpt is strengthened by its conflation with Phoen. 521 in Ios. 78, a combination shared by Eusebius (Hist. eccl. 2,18). Assuming that this shared conflation is not mere coincidence, it must be the case that either (i) Eusebius derived it from Philo, or (ii) they had independent access to a source containing the conflation. Against (i) it should be noted that Eusebius was apparently unaware of Philo's Ios., as it is absent from his enumeration of the latter's works (Hist. eccl. 2,18). Note also that Philo, Leg. 3,201-202 which quotes fr. 687 Kannicht is included by von Arnim among the fragments of Chrysippus (SVF 3,676).

31 Although Philo inserts no break preceding fr. 689 Kannicht, but quotes it in continuity with 688, it is probable that the speaker of 689 and 690 is Syleus; see Pechstein 1998, 263-64. 
Philo moves on to summarize in brief what happens next: Syleus did in fact purchase Heracles, who not long thereafter indulges himself on his master's meat and wine:

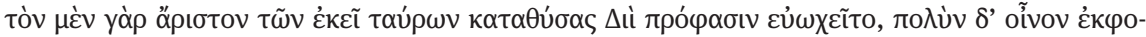

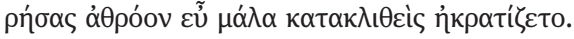

Having sacrificed the best of the bulls there to Zeus as a pretense, he was feasting, and having plundered much wine, he consumed it unmixed all at once after reclining very happily. (Prob. 102)

Syleus returns from the field and angrily confronts his gluttonous slave. Still, Heracles is undaunted and in the final fragment quoted by Philo he dares his "master" to a drinking contest:

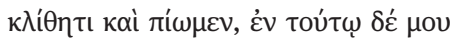

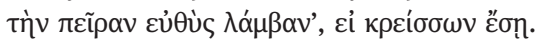

Lie down, and let us drink; take the test at once to see whether in this you are stronger than I. (Prob. 103; fr. 691 Kannicht)

With this humorous conclusion, Heracles' unwavering persistence in excessive eating and drinking establish him as a true master rather than a slave, as his comic persona shines through. ${ }^{32}$ This reveals, Philo argues, that it is rather the institution of

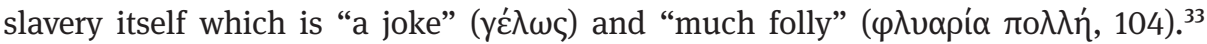

With this play, then, unlike many other instances, Philo has done much more than merely adopt a second-hand quotation. Whereas his use of fr. 687 fits such a model, his expanded discussion together with further quotations and summary of the play exhibits a sustained engagement with his source. Of course, we cannot be certain by what means Philo acquired these 17 lines, but it is clearly possible that he had access to a complete or abbreviated text of the Syleus. ${ }^{34}$

32 Defeating his foes in eating and drinking competitions is attested elsewhere for Heracles; see, e.g., Athenaeus 10,411e-412b on Lepreus. Heracles as a buffoon, a glutton and drunkard, was a stock character in Greek comedy (cf. Athenaeus 10,411b). This is evident in the earliest surviving fragments (e.g., Epicharmus, fr. 18 Kassel-Austin), and had developed into a stereotype by the time of Aristophanes (see Pax 741-742; Av. 1604; cf. Ra. 503-548; Eur. Alc. 747-772). See Hošek 1963. If we accept Dio Chrysostom's assessment, the Alexandrians were especially fond of this comic hero. While they are not amused by drunken slaves on stage in general, Dio claims that "they think it hilarious when they see such a Heracles carried about and, as customary, dressed in saffron" (Tòv $\delta \dot{\varepsilon}$

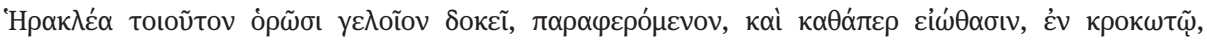
Or. 32,94). Early Christian writers seize upon the excessive of Heracles in their denunciations of paganism (e.g., Orig. c. Cels. 3,22; Euseb. Theoph. 3,61; Lactant. Div. inst. 1,9).

33 Philo omits the conclusion of the myth in which Heracles diverts a river in order to flood Syleus' fields and ultimately kills him and his daughter; see Apollod. 2,6,3; Diod. Sic. 4,31,7; Tzetz. Chil. 2,435; Prol. Com. 2,59-70; for discussion, Pechstein 1998, 252-254.

34 Classical satyr plays were apparently still performed in the imperial period; on evidence from Asia Minor, see Graf 2015. Helm 1906, 141-144, following Hense 1892, 224-28 proposed that Philo may 


\section{Philo in the Alexandrian Audience?}

Having surveyed Philo's textual engagements with Euripidean excerpts, we can now consider the question of his attendance at the theater. Among the five plays of Euripides quoted by Philo in the Probus, in the case of one, he claims to have seen it performed:

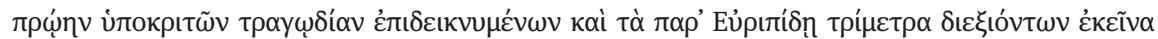

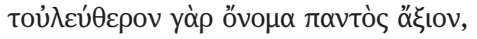

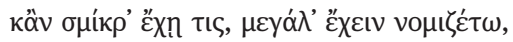

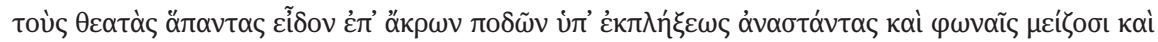

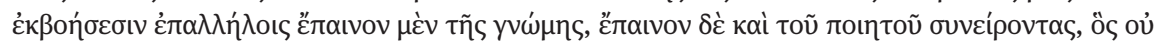

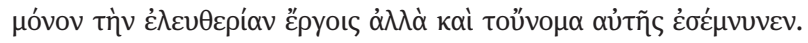

Recently when actors were performing a tragedy and they came through these trimeters by Euripides -

Freedom is a name worthy of everything, even if someone has little, let him understand that he has much (fr. 275,3-4 Kannicht) -

I saw all the audience members standing up on their tip-toes from amazement, and with great voices and responsive shouts jointly declaring their praise of the maxim and praise also of the poet, who revered not only freedom in actions but also its very name. (Prob. 141) $)^{35}$

This passage is one of two instances in which Philo mentions attending a play (see also Ebr. 177), and it is worth exploring its implications. Like other elite Greeks and Romans, Philo can be critical of public entertainments and he disliked the spectacles of games and festivals (Agr. 35, 111-126). ${ }^{36}$ Professional actors were much derided, and in keeping with this Philo disdained Emperor Gaius for his theatrical pretensions, not least because he impersonated gods and demigods in a misguided attempt to attain divine honors (Legat. 78-113; see also Suet. Calig. 54,2; Cass. Dio 59,5,5). Moreover, Philo likens Gaius' treatment of the Jews to a theatrical production of trag-

have taken these lines from the Cynic Bion of Borysthenes, who according to Stobaeus $(3,2,38 ; 4,19,42$ = F11 Kindstrand) wrote "virtuous slaves are free, but wicked freemen are slaves of many passions"

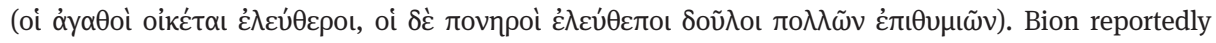

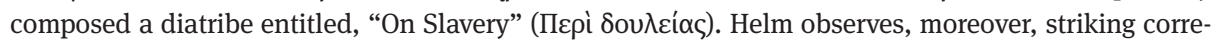
lations between the Syleus and Cynic valorization of Heracles in Lucian's Philosophies for Sale. When

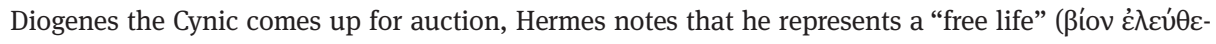
$\rho o v, 7)$. A prospective buyer fears him due to his savage appearance, not least that he "wields a club"

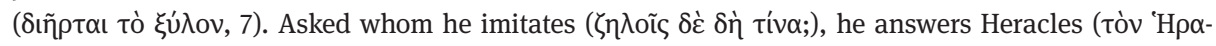
$\kappa \lambda \varepsilon \dot{\varepsilon} \alpha, 8)$, though his is a figurative rather than literal lion's skin. While these parallels are striking and relevant, direct textual evidence for the use of the Syleus in Cynic writings is entirely absent, and consequently Hense's and Helm's theory of Philo's dependence remains inconclusive.

35 Although Philo does not provide the play's title, it is identified as the Auge by Stobaeus, who quotes the same fragment with two additional lines $(4,8,3)$.

36 On this Roman sentiment, see Edwards 1993, 98-136. 
edy (Legat. 233-236, 349-367). ${ }^{37}$ Such moral sentiments regarding the theater, it seems, however, did not keep people away from performances of plays.

Two features of Philo's depiction of his own experience attending the theater should be pointed out. First, he was apparently more interested in the reaction of the audience than the play itself. This emerges from the structure of the sentence, in that the quotation is embedded within a genitive absolute ("when the actors

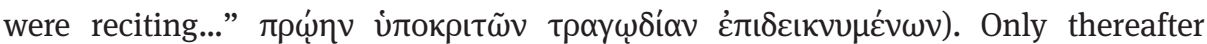

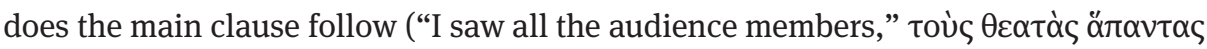

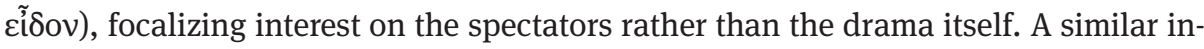
terest underlies Philo's other mention of theater attendance in Ebr. 177, where he notes the range of responses in the audience to illustrate how various stimuli affect people differently. In this way, Philo distances himself from the audience, positioning himself as a meta-observer of the tragedy. ${ }^{38}$

Second, it is relevant that Philo identifies Euripides as the playwright of the performance he attended. This is not surprising given his popularity throughout antiquity, but there is an additional dimension to be considered. Euripidean performances had a distinct intellectual pedigree; in particular, Socrates, a nearly-universal philosophical hero, was reputed to have been especially fond of this playwright. ${ }^{39}$ While this connection had been ridiculed by Aristophanes ( $R a$. 1491-1499), in the later biographical tradition details of their relationship grew and came to be viewed in a more positive light. It was said in the Vita of Euripides that Socrates collaborated with him in composition (Vit. Eur. T 1, IA,3 Kannicht). ${ }^{40}$ Moreover, Diogenes Laertius reports that Socrates attended the Auge, the very same play apparently viewed by Philo; in the case of Socrates, however, the philosopher disapproved of at least one aspect of the play's moral sentiment $(2,22)$. In addition, Aelian claims that Socrates rarely attended the theater, except when Euripides was staging a new play ( $V H$ 2,13 = T 47a Kannicht). This tradition of Socrates' partiality for Euripides, provides a clear incentive for Philo to place himself in that audience. While this need not cast doubt on the historical veracity of Philo's theater-attendance, it does highlight the intellectual self-fashioning underlying it. That is, it is possible to take his claim at face value: Philo heard the two trimeters in a performance and recalled them suffi-

37 See Friesen 2015b, 90 -92; Friesen 2017. Philo was similarly contemptuous of Flaccus' treatment of the Jews in Alexandria, especially because of its theatricality (e. g., Flacc. 34-39; 72); see Calabi 2003; Bloch 2009, 73-74; Jay 2017.

38 Jay 2013, 226 compares Philo's approach to the theater with Horace's comment (Ep. 2,1,197-198) on Democritus who likewise watched the crowd more than the show. A similarly detached mode of viewing tragedy is advocated by Epictetus, who warns against identifying with the grief of tragic suffering; rather, he counsels the sage to find in tragedy illustrations of undue fixation on externals (Epict. Diss. 1,4,26). On this, see Nussbaum 1993, 128-130; Halliwell 2005, 405-409.

39 On the possibility and nature of an interaction between Socrates and Euripides, see Dodds 1964, 186-188; Irwin 1983; Dillon 2004, $70-73$.

40 Also Diog. Laert. 2,18; cf. T 2,4; T 3,2 Kannicht. On the Vita, see Lefkowitz 1979; Lefkowitz 2012, $87-103$. 
ciently to reproduce them later in his treatise. It is suggestive, however, that the very same lines also appear as an excerpt in Stobaeus, raising the possibility that Philo in fact encountered them via a gnomic anthology as he did in so many other cases. ${ }^{41}$

\section{Conclusions}

I conclude briefly by returning to my opening question: how and why did Philo appropriate the dramas of Euripides? The texts surveyed herein have indicated the commonest reason Philo quotes the playwright is to bolster or illustrate a philosophical argument. In this regard, Philo's approach to Euripides is not unique. Indeed, Euripides' reputation as the "philosopher of the stage," reveals that this approach was commonplace. Many of the excerpts deployed by Philo are frequently found in other authors often addressing similar topics ranging from metaphysics to ethics. This leaves the clear impression that Philo's Euripidean verses came to him second hand, already excerpted as gnomic aphorisms or embedded within established philosophical discourse. This is the case even when Philo claims to have heard the verses for himself performed in the theater. With his attendance of Euripides, Philo places himself squarely in a philosophical tradition connected with Socrates. Yet, whereas much of Philo's engagement with this playwright is plainly derivative, one case stands out as a counterexample: Philo quotes five fragments from the Syleus, four of which are unattested elsewhere. Along with these verses, he displays considerable knowledge of the play, summarizing its dramatic action.

What emerges clearly from this study is that Euripides continued to be a popular poet in first-century Roman Alexandria. In particular, his dramatic poetry - both tragedy and satyr play - was of interest not merely to educated "pagan" Greeks and Romans, but also to a Jewish intellectual, one immersed in biblical law and piety.

\section{Bibliography:}

Alexandre 2009: Manuel Alexandre Jr., "Philo of Alexandria and Hellenic Paideia", Euphrosyne 37, $121-130$.

Alexandre 1967: Monique Alexandre, “La culture profane chez Philon”, in: Roger Arnaldez, Claude Mondésert, and Jean Poilloux (edd.), Philon d' Alexandrie, Paris, 105-129.

Arnaldez and Pouilloux 1969: Roger Arnaldez and Jean Pouilloux, De aeternitate mundi (Les oeuvres de Philon d'Alexandrie, 30), Paris.

41 In two other instances where Philo quotes Euripidean fragments as gnomic sayings, the same fragment is preserved in a fuller form by Stobaeus: Antiope fr. 200 Kannicht in Spec. 4,47 and Stob. 4,13,3; Ino fr. 420 Kannicht in Somn. 1,154; Mos. 1,31; and Stob. 4,41,1. 
Berthelot 2011: Katell Berthelot, "Philon d'Alexandrie, lecteur d'Homère: quelques éléments de réflexion", in: Anne Balansard, Gilles Dorival, and Mireille Loubet (edd.), Prolongements et renouvellements de la tradition classique, Aix-en-Provence, 145-157.

Bloch 2009: René Bloch, "Von Szene zu Szene: Das jüdische Theater in der Antike”, in: Matthias Konradt and Rainer Christoph Schwinges (edd.), Juden in ihrer Umwelt: Akkulturation des Judentums in Antike und Mittelalter, Basel, 57-86.

Calabi 2003: Francesca Calabi, “Theatrical Language in Philo's In Flaccum”, in: Francesca Calabi (ed.), Italian Studies on Philo of Alexandria (Studies in Philo of Alexandria and Mediterranean Antiquity, 1), Boston, 91-116.

Chadwick 1969: Henry Chadwick, “Florilegium”, in: Theodor Kluser, Franz J. Dölger, and Ernst Dassmann (edd.), Reallexikon für Antike und Christentum, vol. 7, Stuttgart, 1131-1159.

Collins 1997: John J. Collins, Jewish Wisdom in the Hellenistic Age, Louisville.

Cribiore 2001: Raffaella Cribiore, Gymnastics of the Mind: Greek Education in Hellenistic and Roman Egypt, Princeton.

Dillon 2004: John M. Dillon, "Euripides and the Philosophy of His Time", Classics Ireland 11, 47-73.

Dodds 1964: Eric Robert Dodds, The Greeks and the Irrational, Berkeley.

Doering 2005: Lutz Doering, "Excerpting Texts in Second Temple Judaism: A Survey of the Evidence", in: Rosa Maria Piccione and Matthias Perkams (edd.), Selecta colligere, II: Beiträge zur Technik des Sammelns und Kompilierens griechischer Texte von der Antike bis zum Humanismus, Alessandria, 1-38.

Edwards 1993: Catharine Edwards, The Politics of Immorality in Ancient Rome, Cambridge.

Friesen 2015a: Courtney J. P. Friesen, “Hannah's 'Hard Day' and Hesiod's 'Two Roads': Poetic Wisdom in Philo's De ebrietate", Journal for the Study of Judaism 46, 44-64.

Friesen 2015b: Courtney J. P. Friesen, Reading Dionysus: Euripides' Bacchae and the Cultural Contestations of Greeks, Jews, Romans, and Christians (Studien und Texte zu Antike und Christentum, 95), Tübingen.

Friesen 2016: Courtney J. P. Friesen, “Dying Like a Woman: Euripides’ Polyxena as Exemplum between Philo and Clement of Alexandria", Greek, Roman, and Byzantine Studies 56, 623-645.

Friesen 2017: Courtney J. P. Friesen, "Virtue and Vice on Stage: Philo of Alexandria's Theatrical Ambivalences", in: Lutz Doering and Sandra Gambetti (edd.), Jews and Drama (Journal of Ancient Judaism Supplements), Göttingen.

Fuglseth 2006: Kåre Sigvald Fuglseth, "The Reception of Aristotelian Features in Philo and the Authorship Problem of Philo's De aeternitate mundi”, in: David Brakke, Anders-Christian L. Jacobsen, and Jörg Ulrich (edd.), Beyond Reception: Mutual Influences between Antique Religion, Judaism and Early Christianity (Early Christianity in the Context of Antiquity), Frankfurt, 57-67.

Galinsky 1972: G. Karl Galinsky, The Herakles Theme: The Adaptations of the Hero in Literature from Homer to the Twentieth Century, Oxford.

Garland 2004: Robert Garland, Surviving Greek Tragedy, London.

Graf 2015: Fritz Graf, "Comedies and Comic Actors in the Greek East: An Epigraphical Perspective", in C. W. Marshall and Tom Hawkins (edd.), Athenian Comedy in the Roman Empire, London, 117-129.

Gruen 2001: Erich S. Gruen, "Jewish Perspectives on Greek Culture and Ethnicity", in: John J. Collins and Gregory E. Sterling (edd.), Hellenism in the Land of Israel (Christianity and Judaism in Antiquity, 13), Notre Dame, 62-93

Halliwell 2005: Stephen Halliwell, "Learning from Suffering: Ancient Responses to Tragedy", in: Justina Gregory (ed.), A Companion to Greek Tragedy, Oxford, 394-412. 
Heath 1987: Malcom Heath, “Jure principem locum tenet': Euripides' Hecuba”, Bulletin of the Institute of Classical Studies 34, 40-68.

Helm 1906: Rudolf Helm, Lucian und Menipp, Leipzig.

Hense 1892: Otto Hense, “Bion bei Philon”, Rheinisches Museum für Philologie 47, 219-240.

Irwin 1983: Terence Irwin, "Euripides and Socrates", Classical Philology 78, 183-197.

Hošek 1963: Radislave Hošek, "Herakles auf der Bühne der alte attischen Komödie”, in: Ladislav Varcl and Ronald F. Willetts (edd.), GERAS: Studies Presented to George Thomson on the Occasion of his 60th Birthday (AUC Philosophica et historica, 1, Graecolatina Prasgensia, 2), Prague, 119-127.

Jay 2013: Jeff Jay, "The Problem of the Theater in Early Judaism”, Journal for the Study of Judaism 44, $218-253$.

Jay 2017: Jeff Jay, “Spectacle, Stage-Craft, and the Tragic in Philo's In Flaccum: A Literary Analysis" in: Lutz Doering and Sandra Gambetti (edd.), Jews and Drama (Journal of Ancient Judaism Supplements), Göttingen.

Kidd 1996: Ian G. Kidd, "Theophrastus fr. 184 FHS\&G: Some Thoughts on His Arguments", in: Keipme A. Algra, Pieter W. van der Horst, David T. Runia (edd.), Polyhistor: Studies in the History and Historiography of Ancient Philosophy Presented to Jaap Mansfeld, Leiden, 135-144.

Konstan 2010: David Konstan, “Excerpting as a Reading Practice”, in: Gretchen Reydams-Schils and Carlos Lévy (edd.), Deciding Culture: Stobaeus' Collection of Excerpts of Ancient Greek Authors, Turnhout, 9-22.

Koskenniemi 2006: Erkki Koskenniemi, “Philo and Classical Drama”, in: Jacob Neusner, Alan J. Avery-Peck, Antti Laato, Risto Nurmela, and Karl-Gustav Sandelin (edd.), Ancient Israel, Judaism, and Christianity in Contemporary Perspective: Essays in Memory of Karl-Johan Illman (Studies in Judaism), Lanham, Md., 137-151.

Koskenniemi 2010: Erkki Koskenniemi, "Philo and Greek Poets", Journal for the Study of Judaism 41, 301-322.

Koskenniemi 2014: Erkki Koskenniemi, “Philo and Classical Education”, in: Torrey Seland (ed.), Reading Philo: A Handbook to Philo of Alexandria, Grand Rapids, 102-128.

Lefkowitz 1979: Mary R. Lefkowitz, “The Euripides Vita”, Greek, Roman, and Byzantine Studies 20, $187-210$.

Lefkowitz 2012: Mary R. Lefkowitz, The Lives of the Greek Poets (2d ed.), Baltimore.

Lévy 2005: Carlos Lévy, “Deux problèmes doxographique chez Philon d'Alexandrie: Posidonius et Enésidème”, in: Aldo Branacci (ed.), Philosophy and Doxography in the Imperial Age, Florence, 79-102.

Lincicum 2013a: David Lincicum, “Aeschylus in Philo, Anim. 47 and QE 2.6”, Studia Philonica 25, 65-68.

Lincicum 2013b: David Lincicum, “A Preliminary Index to Philo's Non-Biblical Citations and Allusions”, Studia Philonica 25, 139-167.

Mattila 1996: Sharon Lea Mattila, “Wisdom, Sense Perception, Nature, and Philo’s Gender Gradient", Harvard Theological Review 89, 103-129.

Mendelson 1982: Alan Mendelson, Secular Education in Philo of Alexandria (Monographs of the Hebrew Union College, 7), Cincinnati.

Morgan 2003: Teresa Morgan, "Tragedy in the Papyri: An Experiment in Extracting Cultural History from the Leuven Database", Chronique d'Égypte 78, 187-201.

Niehoff 2001: Maren R. Niehoff, Philo on Jewish Identity and Culture (Texts and Studies in Ancient Judaism, 86), Tübingen.

Niehoff 2006: Maren R. Niehoff, “Philo's Contribution to Contemporary Alexandrian Metaphysics", in: David Brakke, Anders-Christian L. Jacobsen, and Jörg Ulrich (edd.), Beyond Reception: 
Mutual Influences between Antique Religion, Judaism and Early Christianity (Early Christianity in the Context of Antiquity), Frankfurt, 33-55.

Niehoff 2011: Maren R. Niehoff, Jewish Exegesis and Homeric Scholarship in Alexandria, Cambridge.

Niehoff 2012: Maren R. Niehoff, "Philo and Plutarch on Homer", in: Maren R. Niehoff (ed.) Homer and the Bible in the Eyes of Ancient Interpreters (Jerusalem Studies in Religion and Culture, 16), Leiden, 127-153.

Nieto Hernández 2014: Pura Nieto Hernández, “Philo and Greek Poetry”, Studia Philonica 26, $135-149$.

Nussbaum 1993: Martha C. Nussbaum, "Poetry and the Passions: Two Stoic Views", in: Jacques Brunschwig and Martha C. Nussbaum (edd.), Passions and Perceptions: Studies in Hellenistic Philosophy of Mind, Proceedings of the Fifth Symposium Hellenisticum, Cambridge, 97-149.

Oertelt 2015: Friederike Oertelt, Herrscherideal und Herrschaftskritik bei Philo von Alexandria: Eine Untersuchung am Beispiel seiner Josephsdarstellung in De Josepho und De somniis II (Studies in Philo of Alexandria, 8), Leiden.

Pechstein 1998: Nikolaus Pechstein, Euripides Satyrographos: Ein Kommentar zu den Euripideischen Satyrspielfragmenten (Beiträge zur Altertumskunde, 115), Stuttgart.

Petit 1974: Madeleine Petit, Quod omnis probus liber sit (Les oeuvres de Philon d'Alexandrie, 28), Paris.

Runia 1981: David T. Runia, “Philo's De aeternitate mundi: The Problem of Its Interpretation”, Vigiliae christianae 35, 105-151.

Runia 2008: David T. Runia, "Philo and Hellenistic Doxography”, in: Franscesca Alesse (ed.), Philo of Alexandria and Post-Aristotelian Philosophy (Studies in Philo of Alexandria), Leiden, $13-54$.

Sedley 1998: David Sedley, "Theophrastus and the Epicurean Physics", in: Johannes van Ophuisjen and Marlein van Raddlte (edd.), Theophrastus: Reappraising the Sources, New Brunswick, 331-354.

Sutton 1980: Dana F. Sutton, The Greek Satyr Play (Beiträge zur klassischen Philologie, 90), Meisenheim am Glan.

Wiersma 1940: W. Wiersma, "Der angebliche Streit des Zenon und Theophrast über die Ewigkeit der Welt", Mnemosyne 3, 235-243. 